\title{
SETTLEMENT AS A TOURISM ATTRACTIONS Case Study : Banjar Karang Dalem I Settlement, Desa Bongkasa Pertiwi, Badung Regency, Bali-Indonesia
}

\section{Made Suryanatha Prabawa ${ }^{1}$ Anak Agung Gede Raka Gunawarman ${ }^{2}$}

1,2 Architecture Dept. Universitas Warmadewa, Denpasar, Indonesia Corresponding author : prabawa@warmadewa.ac.id 1, gunawarman@warmadewa.ac.id ${ }^{2}$

$$
\begin{array}{cccc}
\multicolumn{4}{c}{\text { Article History: }} \\
\text { Received: } 5 \text { November } & \text { Revised: } 25 \text { November } & \text { Accepted: } 15 \text { December } & \text { Available online: } 18 \text { December } \\
2020 & 2020 & 2020 & 2020
\end{array}
$$

\begin{abstract}
Tourism Village is related to Community-Based Tourism (CBT) where all management and development includes the participation of local communities. Badung Regency launched 11 Badung Tourism Villages through Perbup no. 47 of 2010. 1 of 11 Tourism Villages that are declared is Bongkasa Pertiwi Village. In Perbup it is very clear that Br. Karang Dalem I, the residents and their settlements should become icons of village tourism. The issue that was caught in the field was that embedding it as a tourist village did not have a positive impact on the settlement at Br. Karang Dalem I, Bongkasa Pertiwi Village, where some of its residents are pursuing a unique profession, namely traditional silver craftsmen. The craftsman profession, which used to be the majority, now only has 8 residents working (previously almost every household) and none of them are young. This issue is the basis for the need to conduct further studies to find the tourism potential of the Br. Karang Dalem I as a settlement for silversmiths in line with Bongkasa Pertiwi Village as a Tourism Village. The purpose of this study was to explore, collect data, analyze the spatial aspects of the settlement of Br. Karang Dalem I which is somewhat unique (Typical / Traditional) with an understanding of the meaning behind the existence of this spatial aspect, because initial observations of several settlements still maintain their traditional architectural form. This research is supported by an understanding of the concept of a tourism village, tourism architecture as a core, Balinese traditional settlements, and a study on the development of the tourism village of Bongkasa Pertiwi as previous research. This study will use an exploratoryqualitative method with cross-examination data analysis to obtain the best research conclusions. This research findings shows that architectural components of Banjar Karang Dalem I settlement are classified as special tourism interest (WMK). The Data show that 6 (six) aspects of sepcial tourism interest are found in Banjar Karang Dalem I settlement such as Settlement Layout Pattern, Telajakan Garden, The use of Kori as entrance gate, House using "Natah" As Arrangement Pattern, etc.
\end{abstract}

Keywords : Tourism Villages, Settlement, Tourism Potencies

\section{Introduction}

Tourism sector is the largest revenue contributor for the province of Bali. For the last 4 years, the amount of foreign tourist visits was increasing gradually each year. Because of its promising revenue, most of Balinese people depends on it to be able to support their families. Nowadays either regionally or globally, tourism developments facing a serious challenge, especially when connected to globalisation era. Globalisation era related to utilization of technology development and changes in behavior patterns of international tourists. Challenge responded by 
Indonesian Government by appealed to all that tourism development must be using CommunityBased Tourism (CBT) Concept., which emphasizes a unique local people environment and supported by a development concept and strategy based on digital technology (Prasyanti, 2019). Desa Wisata or Tourism Village was a form of CBT that currently discussed by many experts. Desa Wisata was a tourism development concept that targeting a settlement area in an administrative form of Desa which has uniques potencies of tourism attractions.

Penglipuran village, Tenganan Village, could be seen as a real example of Tourism Village practice, because those villages has an uniqueness, especially fom its settlement architecture. Each village has uniqueness in house layout, village layout, entrance form, tradition, etc. those components make the village unique and worthy to visit. Seeing from these phenomenon settlement can be understood as an arrangement of space masses which contains combination of complex aspects because it is related to social aspects; economy aspects; cultural aspects; ecological aspects; etc - those aspects related directly to human and its dwelling environments (Ristianti, 2015). In the field of architecture in particular, settlements are mass structures of buildings called houses, standing or present houses as a result of the practice of living (human beings with lifelihoods and livelihoods). Because of the closeness of the presence of the house with the characteristics of humans in their living activities, each house in a certain area has its own uniqueness. In the realm of settlements, or hereinafter the architecture of human settlements is gathered in a site so that it becomes a collection of people called the community - hereinafter the collection of their houses is called a settlement. This understanding gives an idea that each settlement must have its own uniqueness and can be developed in a certain direction according to its unique potential.

Bongkasa Pertiwi Village was one of eleven Tourism Villages that has been appointed by the Regent of Badung Regency through Peraturan Bupati Nomor 47 Tahun 2010 (Badung, 2010). In Bongkasa Pertiwi Village there is one profession that can be said to be a unique and distinctive tourism potential, namely the Traditional Silver Crafting. Uniquely, in the area of Badung Regency, these traditional craftsmen can only be found in Banjar Karang Dalem I Settlement, Bongkasa Pertiwi Village.
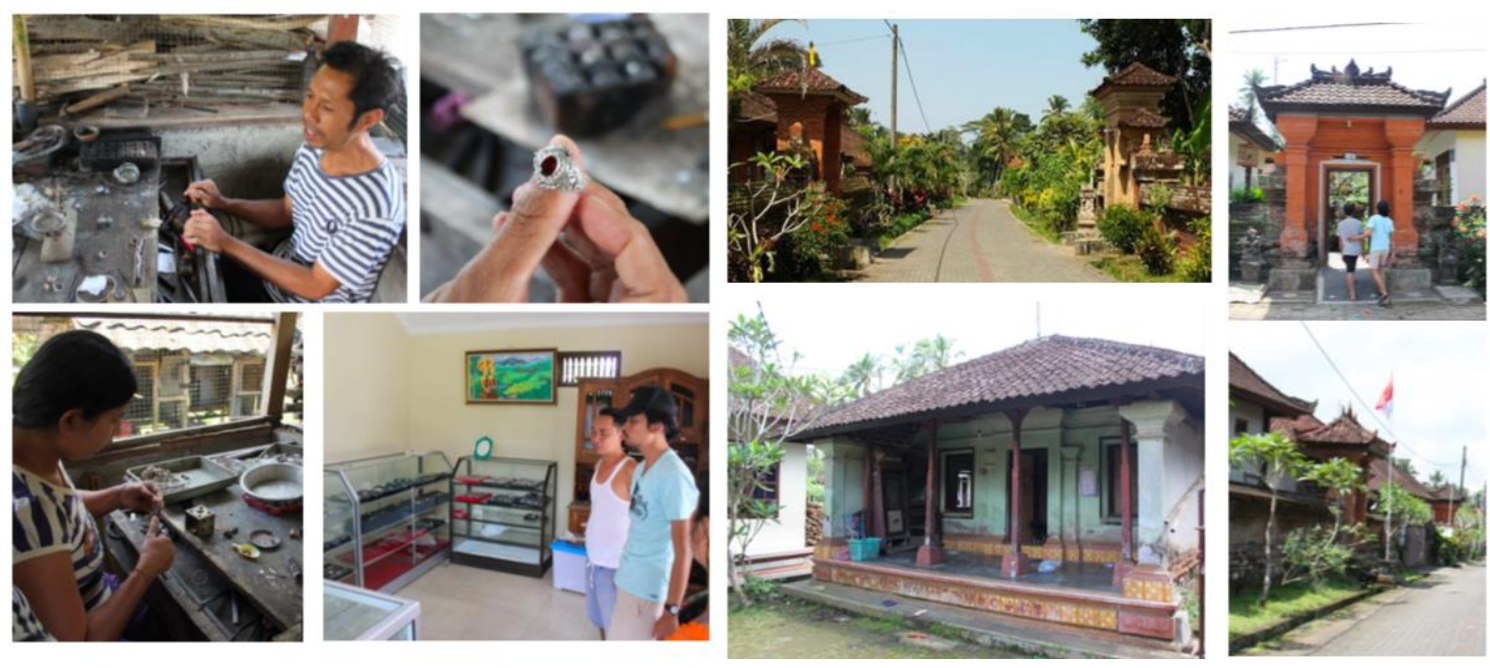

Figure 1: Traditional Silver Crafting and Banjar Karang Dalem I Settlements, 2020. Source: Researcher Documentation

The settlement of these traditional silversmiths in Banjar Karang Dalem I is also unique. Based on the results of the initial visit to the location (grand tour), the majority of the houses in their settlements still maintain traditional architectural patterns, starting from their housing compounds to the layout of their settlements. even some of the building masses in their house compound still stand as they were originally built in the time of their ancestors. The uniqueness of the Silver Craftsmen's Residence is that there are spaces that are used for silver production in the area of their home yards. This condition is related to how. Profession influences and embodies the uniqueness of the residential space. The spatial layout of the settlements is neatly arranged and is like following the concept of Balinese Traditional Settlement Spatial Planning as in Penglipuran Village. The description of the spatial layout is: The neighborhood of the Karang Dalem I banjar 
settlement is composed of rows of angkul-angkul/kori (entrance) and Telajakan gardens. Having a unique environment in terms of settlement, preservation of traditional architecture, and silver handicrafts provide a brief description that this settlement has tourism potential that needs to be studied further.

In this research, literature review in the field of Tourism Village and Architecture and Tourism was done. The purpose was for guiding the research to found important key points to explore. From the review process, Tourism Village was a concept of emphasizing local value or elements of a village as a tourism attraction; tourism base on natural elements (nature-based), Culture, and Adventure (Abdinagoro \& Hamsal, 2019). Tourism Villages must have integration between basic components which is none other than Human ressources and Natural ressources (Sugianto, 2016). Tourism villages also have specific binding criteria, these criteria are Tourist Attractions (natural-cultural physical tourism potential), Level of Community Acceptance and Commitment, Availability of Local Human Resources (HR), Trust and Community Systems, Availability of Infrastructure, and Promotion-Marketing (Primastiana, 2018). Discussing architecture and tourism related to the location of this research leads to some basic theories of tourism, especially regarding tourism products. Tourism products consist of 3 components, namely: (1) Tourism Attraction ; (2) Facilities and Services (Amenities); (3) Ease of Reaching Destinations / Attractiveness (Accesibilities); and (4) the hospitality offered (Sedarmayanti, Sastrayuda, \& Afirza, 2018). Silver Craftsman Settlement Br. Karang Dalem I as an architectural form exists in components 1 and 2. Components (1) Attractions are the main elements that shape and determine an area to become a tourism destination. DTW related to architecture is located in DTW man-made / human-created works such as: Art Buildings, Historical Buildings, Traditional Buildings, Carvings, and Sculptures. Furthermore, component (2) Facilities and Services (Amenities), architecture is closely related to this because the majority of components of the facilities and services supporting DTW are in the built environment.

In this research, it will focus on exploration and analysis related to architectural components of $\mathrm{Br}$. Karang Dalem I settlement which has community-based tourism potential. This research is also expected to help create settlements that can support the village as a tourism village area. Thus, the settlement of Br. Karang Dalem I can be the icon of Bongkasa Pertiwi Village which has been pinned as one of eleven Badung Tourism Villages in Badung Regent.

\section{Methods}

This research uses qualitative-explorative approach. Qualitative approach by using descriptive-anlysis for digging information regarding settlement activities, habit, or cultural, that has tourism attraction value through interview to some resident. Explorative study use for digging information regarding settlement architectural components that has tourism attraction value through direct observation. Through interview, researchers needs to find stories behind architectural components in the settlement area. Through observation, researchers needs to mapping the layout, record the shape, records building ornaments, etc. of each silver craftsman house by simple random sampling, targeting detailed observations on 3 houses as representatives of the Br. Karang Dalem I Settlement.

\section{Results and Discussions}

Through our study process we found some data regarding our study about typology of houses in Kampung Jawa, but first explanation regarding human condition comes first so we would like to mention Kampung Jawa resident's data.

\subsection{Settlements Layout of Banjar Karang Dalem I Settlement}

Settlement of $\mathrm{Br}$. Karang Dalem I is an original or local settlement where the entire composition of the resident's yards follows Balinese Traditional Architecture. In this sub-chapter, the researcher tries to present the results of extracting data related to the spatial arrangement of the residential areas of Br. Karang Dalem I. Spatial Planning related to the Br. Karang Dalem I shows the resilience of Balinese Traditional Settlement Spatial Planning. This resilience is shown in detail by the retention of elements of traditional Balinese settlement layout such as:

\section{Linear Pattern of The Settlement}

The linear pattern is a settlement pattern that is generally adopted by several traditional villages in Bali. One example of a village with a well-known linear settlement pattern is Penglipuran Village in Bangli Regency. Likewise with the settlement of Br. Karang Dalem I which also adheres 
to a linear pattern. The situation around the location shows that other settlements within the scope of Bongkasa Pertiwi Village are not like Br. Karang Dalem I, because most of it has been transformed or not the location of the original house (ngubu). This linear pattern is indicated by one road, namely Jalan Dewi Gangga which is the orientation of the opening or entrance to the residents' yard. Another aspect that reinforces the traditional linear pattern is that at the intersection of the road on the north-east side (Kaja-Kangin) the settlement is Pura Dalem Karang Dalem. Pura Dalem Karang Dalem is a temple or holy place of worship which is emponed by one of the residents in the Br. Karang Dalem I. Furthermore, according to the traditional Balinese culture, the residents of Br. Karang Dalem I can be referred to as "Pengemong Pura" or the one who is obliged to take care of all customary-religious matters related to the presence of the temple as the "ulu" settlement of $\mathrm{Br}$. Karang Dalem I.

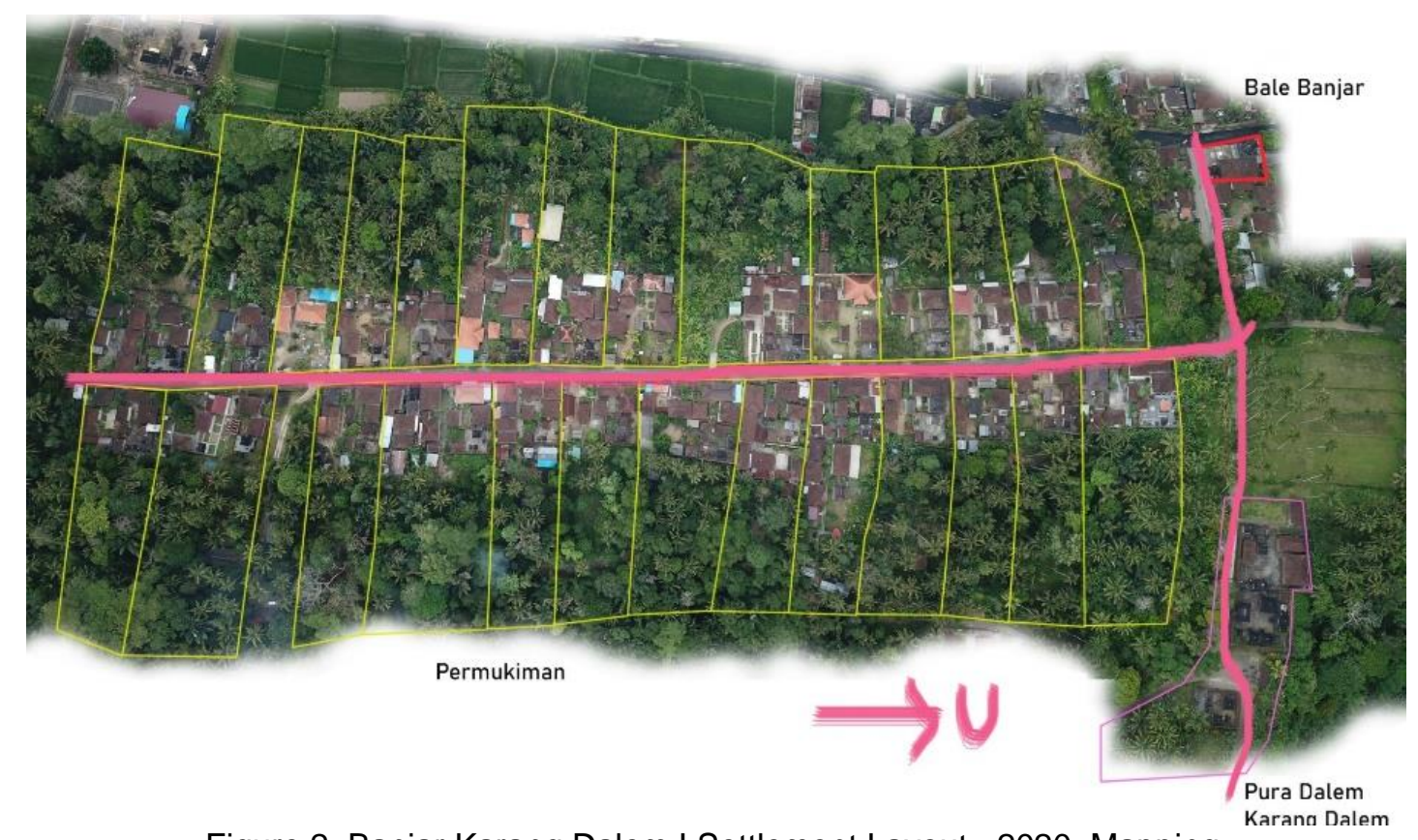

Figure 2: Banjar Karang Dalem I Settlement Layout , 2020, Mapping. Source: Researcher Documentation

\section{“Telajakan" Garden as Settlement Traditional Landscapes}

Telajakan can also be referred to as an element of Balinese traditional landscape / gardening architecture. Telajakan is actually one of the Balinese Traditional Green Open Space (RTH) concepts which refers to the Tri Hita Karana philosophy. Tri Hita Karana are 3 (three) sources of the causes of achieving happiness in life through establishing a harmonious relationship between Man-God-Environment, the main focus here is humans and the environment or palemahan. In general, Tri Hita Karana influences every aspect of the built environment, which is the work of a combination of Balinese Hindu religious traditions. Telajakan in the Settlement of Br. Karang Dalem I is $80 \mathrm{~cm}$ to $120 \mathrm{~cm}$ wide. It is also planted with various Balinese vegetation such as puring (plawa), Balinese plumeria (jepun), bregu palm, sandat, coconut (nyuh), and grass. The majority of vegetation types mentioned earlier are classified as vegetation capable of supporting the sustainability of the customs of the Br. Karang Dalem I, especially in the aspect of upakara (infrastructure offerings to God). Judging from the variety of vegetation, the function of planting, and the visuals, the residential area of Br. Karang Dalem I appears to be very traditional in visual and functional in its planting purpose.

Re-examining the philosophical benefits of Tri Hita Karana is a supporting element of environmental quality (palemahan). (Pradnya Dewi, 2018). With the persistence of the lake, the beauty and health of the environment (oxygen provider) can be maintained. Telecommunications In other residential areas in the village of Bongkasa Pertiwi, the majority have undergone a change of function, such as becoming a rental shop, garage / carport, etc. Only in the Residential Area of Br. Karang Dalem I which still survives as the initial establishment of the settlement. 


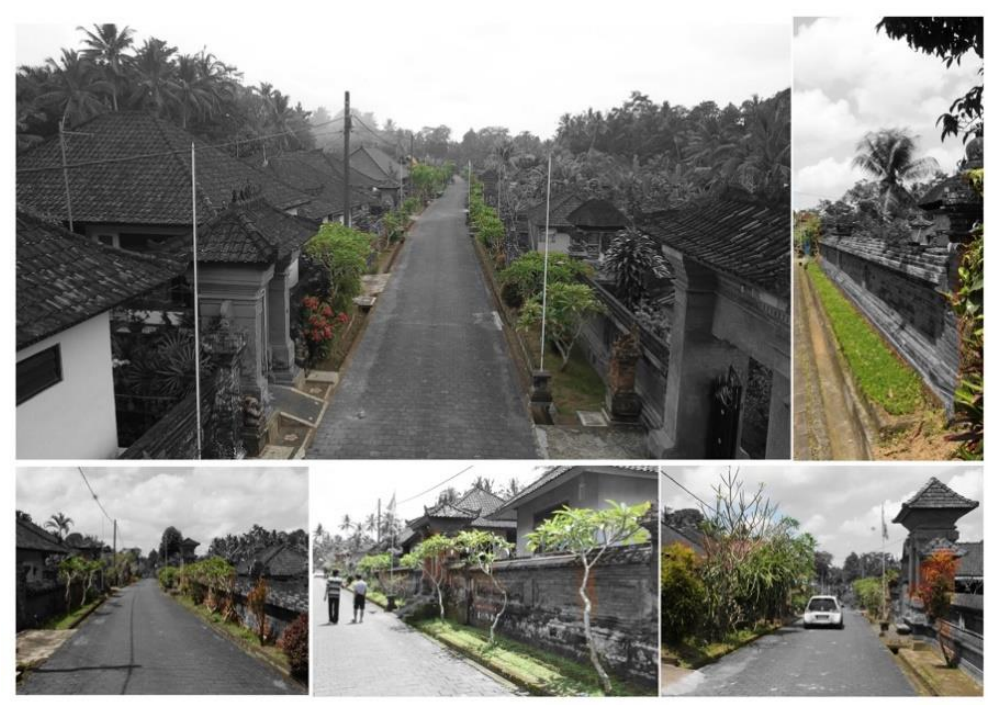

Figure 3: Telajakan Condition in Banjar Karang Dalem I Settlement, 2020. Source: Researcher Documentation

\section{"Kori” or "Angkul-Angkul" (Entrance)}

Kori / Angkul-Angkul is an architectural element of a traditional Balinese entrance that leads to the residents' yards. The majority of Kori Architecture (Form, Style, Layout) still maintains the state as it was originally built. In terms of shape, some of the kori have been renovated to be bigger to show an increase in social status, while others still retain their original shape. Stylistically, most of the Kori buildings still use the dominant brick material, in which Bata as the main building material is a characteristic of Balinese Traditional Architecture in the scope of the Badung area, or so-called "Bebadungan". Other kori, due to renovation, have adopted other regional styles such as the Karangasem Style (black stone) or Gianyar (rubbing face) style. Overall Layout Kori is still in the position it was originally built.

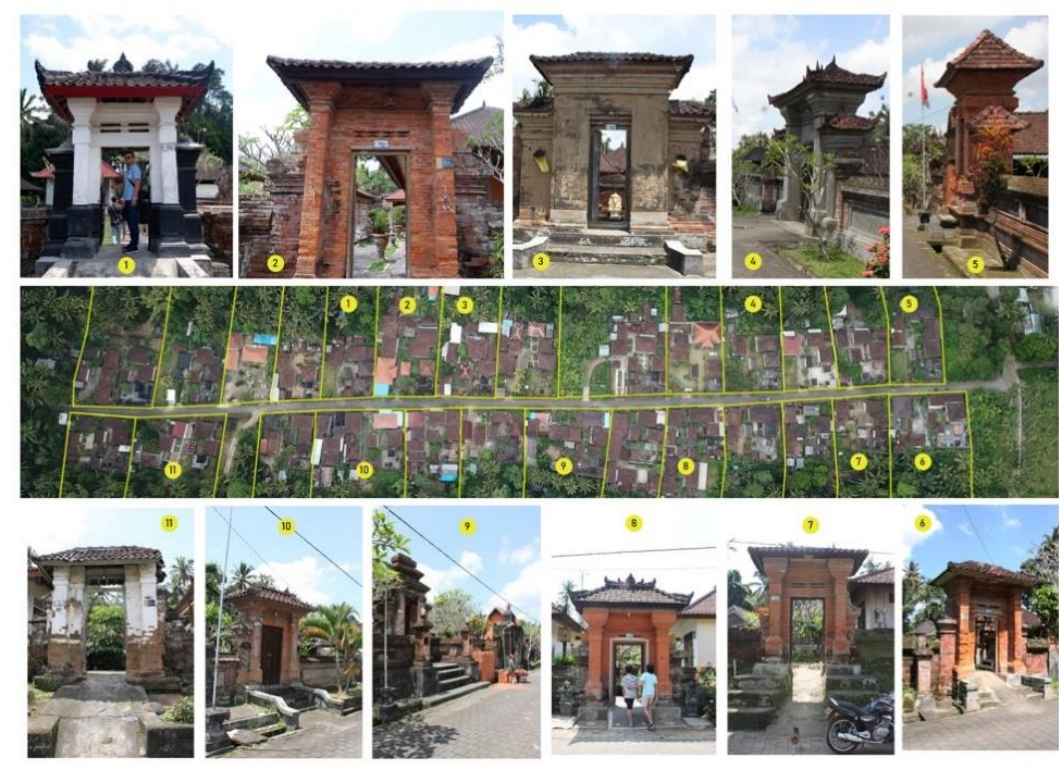

Figure 4: Types of Kori (Balinese entrance) in Banjar Karang Dalem I Settlement , 2020, Mapping. Source: Researcher Documentation

\subsection{House Layout and Condition}

Based on the results of the field review, the majority of houses in the Br. Karang Dalem I still adheres to the "Natah" pattern. The "Natah" pattern is to make the yard as the center of the 
orientation of the whole building. Based on the results of aerial photography, it can also be seen that the whole house even though the condition has been modified, still maintains the yard as the center of the building orientation. Composer materials and architectural styles have changed in several buildings, but overall the buildings still survive and stand based on the traditional Balinese architectural philosophy, namely Tri Hita Karana, Tri Angga, Tri Mandala, Akasa-Pertiwi, Manik Ring Cecupu and so on.

\section{Sample 1}

It is the home of traditional silver craftsmen. This house complex, as has been described in general, adheres to the layout of the "natah" pattern. The "natah" pattern that is applied in building layout is also complemented by the survival of "tebe" or gardens within the scope of the residents' houses which are planted with various food crops and ceremonies such as coconut, mango, plawa, etc. The majority of main buildings still maintain the condition they were originally built (original). The original buildings include: (1) Bale Meten; (2) Bale Sakenem; and (3) sulking. Buildings that have undergone renovations are: (1) Bale Dauh; (2) Paon. What is quite unique in the sample 1 house and other sample targets is that there is a building that functions as a silver handicraft workshop along with the use of several yards as a place for workshop tools. Some of the original buildings in the Sample 1 House Complex are still in good condition and some need restoration. Buildings in good condition are Bale Meten and Merajan, while Bale Sakenem is in a porous condition in some parts. Due to constraints the cost of restoration cannot be carried out by the owner. These original buildings use brick material as the main constituent material and the floors still use earth tiles.

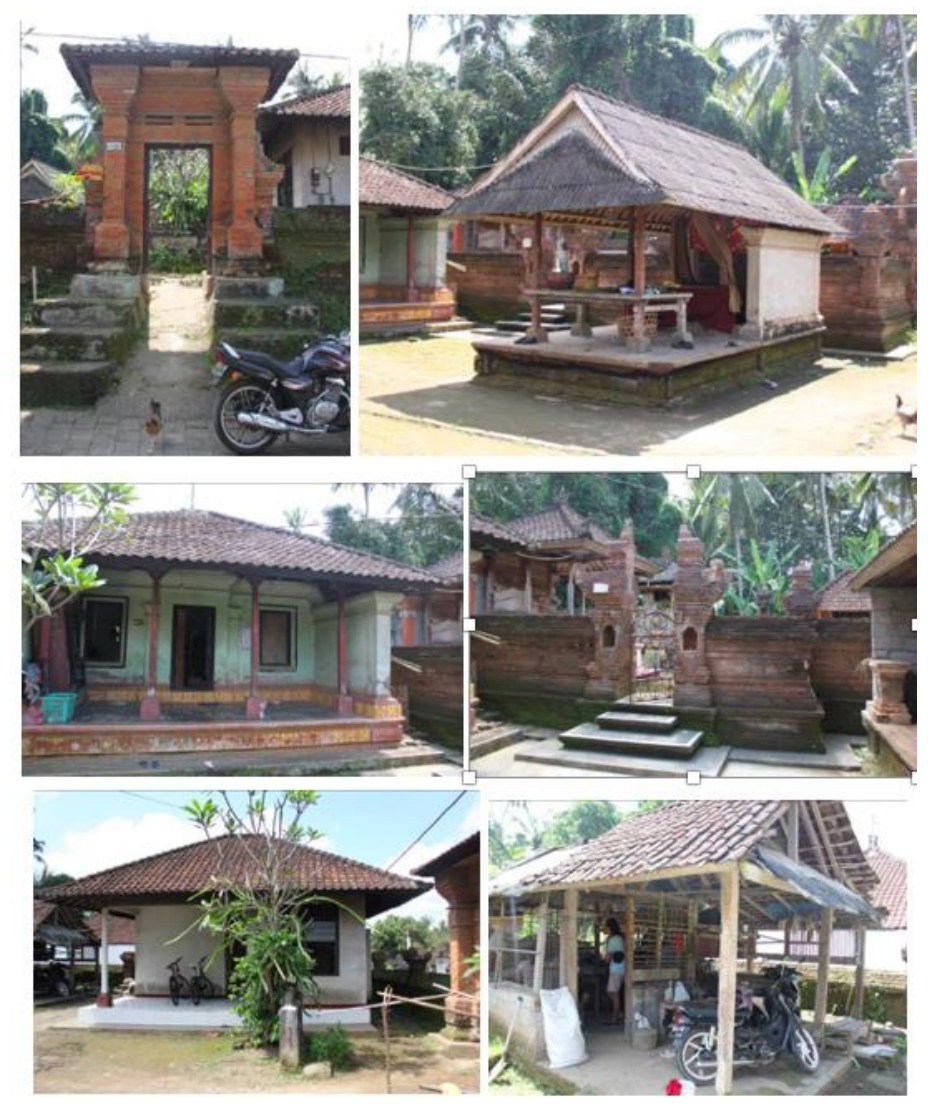

Figure 5: Left-Right : Kori, Bale Sakenem, Bale Meten, Merajan, Paon, and Silver Workshop in Sample 1 house compound, 2020, Photos.

Source: Researcher Documentation

\section{Sample 2}

The Sample 2 House Complex is also a home for silversmiths, but not all members work as craftsmen but only 1 person. Similar to the sample 1 house, the sample 2 house still adheres to the "natah" pattern. The "Natah" pattern is complemented by a "tebe" or garden. The building 
condition of the Sample 2 House Complex is still relatively good because most of the buildings have been renovated. The difference with the sample 1 house is the condition of the bale sakenemn and the meten bale which have been renovated here. This renovation action seems to reduce the impression of authenticity of the building. In this house there is also a special building designated as a silver craft workshop. This room is near Kori (Entrance).

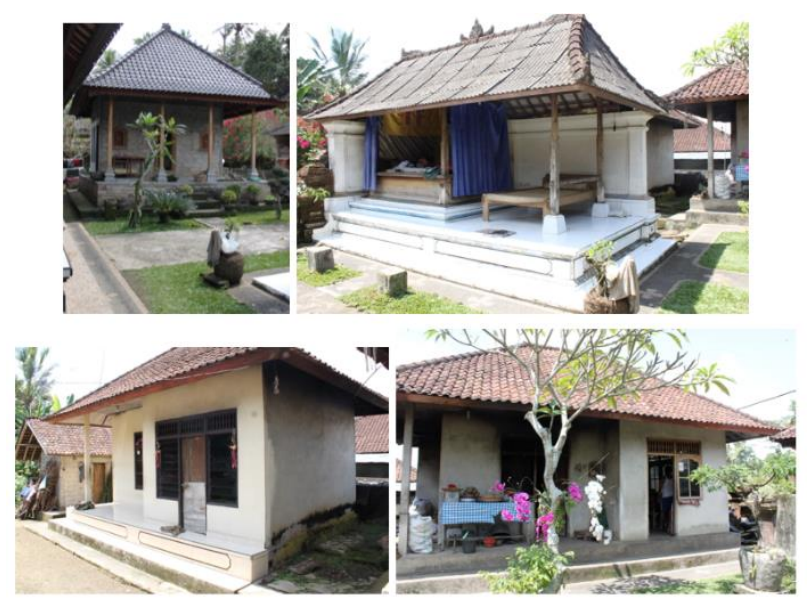

Figure 6: Left-Right : Bale Meten, Bale Sakenem, Kamar Tidur, Paon, and Silver Workshop in Sample 2 House Compound, 2020, Photos.

\section{Sample 3}

Source: Researcher Documentation

The spatial condition of the sample 3 house is still the same as the previous sample which still maintains the "natah" pattern, the difference lies in the condition of the buildings which have all been modified apart from being made up and in the yard area of the house there is a silver craft gallery. Apart from having a private silver gallery, this house also has a fairly large bale workshop. The owner of the house is independently active in offering a tour package for a ring or bracelet making workshop for interested tourists. This Bale Workshop was built on a "tebe" area or a private garden, so that the area of "tebe" in the sample 3 house is not as wide as sample 1 and 2 and some areas have been used for silver processing areas (another workshop area with silver raw material processing area) .
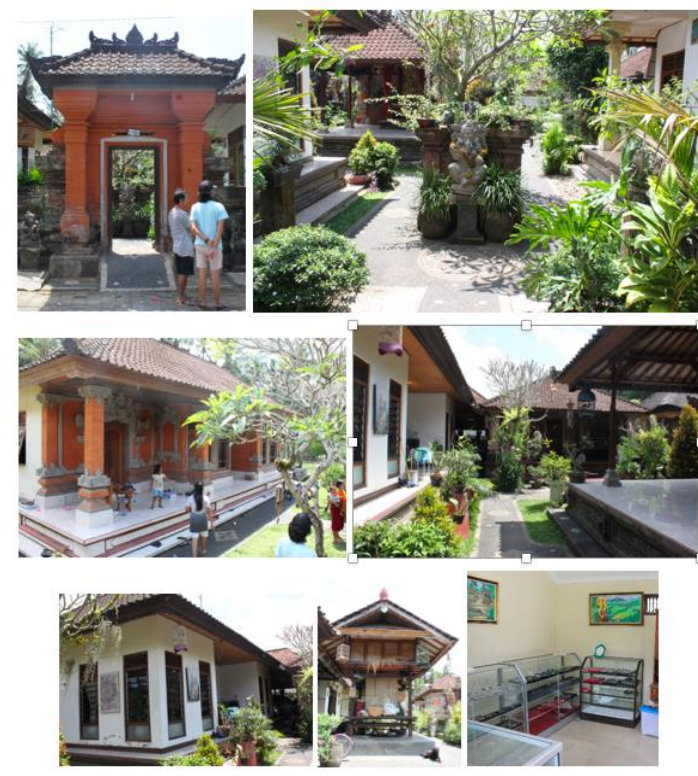

Figure 7: Kori, Natah, Bale Delod, Bale Meten, Bale Dauh, Jineng, and Silver Gallery/Workshop in Sample 3 House Compound, 2020, Photos.

Source: Researcher Documentation 


\subsection{Traditional Silver Crafting}

The part of architecture that is no less important is the functional aspect. The functional aspect relates to how humans make use of the existing space for activities in accordance with their culture. Furthermore, activities become the focus in this section. In general, the unique activities in a traditional Balinese house are well known, such as Wake up in the Morning-Cooking at Paon"Nanding Banten" (preparing offerings) -Mebanten Saiban (Do the daily offerings)- Feeding the Animal (Pigs; Chickens)-Nanding Canang-Mebanten Canang-and so on. Especially for the settlement of Br. Karang Dalem I has a unique activity, namely the activity of making traditional silver handicrafts in the yard of the house. In Bali, a similar settlement may only exist in Celuk Village, Gianyar. However, the condition of this silver handicraft is quite alarming because currently only 8 (eight) of the traditional craftsmen are still active. According to Pak Mela, as the head of a silver craftsman group, along this road every house was busy making silver crafts, but starting in the 1990s because of the persistence of the traditional system and the more rapid progress of silver in Celuk Village, many residents changed their profession to become tourism workers. This phenomenon has an impact on decreasing demand, so that many residents end up not continuing the silver handicraft tradition.

The traditional value of silver in this settlement can be seen from the initial process of forming silver so that it becomes jewelry. The initial process, such as bending silver ("blenes") still uses hand-operated tools, then burning is still using fire with a stepping pump, the preparation of silver components in the main part is still using hands. Tools, Processes, and Skills of the residents can be a unique activity that can only be found in this settlement if there are tourists visiting the Badung area.
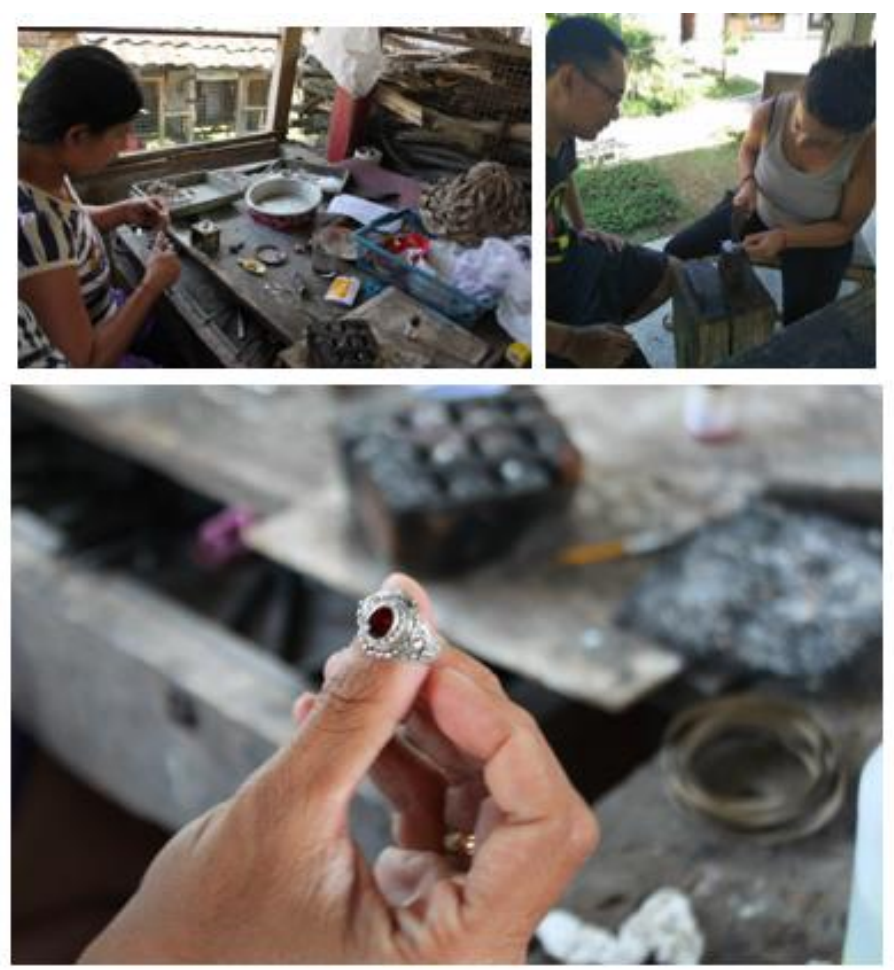

Figure 8: Silver Jewelry Traditional Crafting Process in Banjar Karang Dalem I Settlement, 2020, Photos.

Source: Researcher Documentation

\subsection{Tourism Attraction Potencies Analysis}

Based on the results of extracting data in the previous section, an arrangement of settlement architectural components from the settlement of Banjar Karang Dalem I has tourism potential and is related to tourism theory. 
Table 1

Tourism Attraction Potencies Analysis

\begin{tabular}{|c|c|c|c|}
\hline No. & Architect & $\begin{array}{l}\text { Iral Component in } \\
\text { ettlement }\end{array}$ & Tourism Attraction Potencies \\
\hline \multirow[t]{3}{*}{1} & $\begin{array}{l}\text { Settlement } \\
\text { Layout }\end{array}$ & $\begin{array}{l}\text { Linear Pattern of The } \\
\text { Settlement }\end{array}$ & $\begin{array}{l}\text { 1. Giving a uniqueness from beautiful linear scenery aspects } \\
\text { 2. Able to give philosophical knowledge regarding settlement layout } \\
\text { pattern (Tri Hita Karana Concept Application ) }\end{array}$ \\
\hline & & $\begin{array}{l}\text { Telajakan as } \\
\text { Traditional } \\
\text { Settlement } \\
\text { Landscape }\end{array}$ & $\begin{array}{l}\text { 1. Giving a unique pleasure through beautifull and attractive visual } \\
\text { scenery } \\
\text { 2. Able to give philosophical knowledge regarding Telajakan as a } \\
\text { traditional Balinese landscape design ( Tri Hita Karana Concept } \\
\text { Application ) } \\
\text { 3. Able to explain knowledge regarding local plants that planted on the } \\
\text { Telajakan and also the purposes of its planting. } \\
\text { 4. Giving explanation regarding Telajakan function. }\end{array}$ \\
\hline & & $\begin{array}{l}\text { Sequence of "Kori" in } \\
\text { the Settlement }\end{array}$ & $\begin{array}{l}\text { 1. Giving a unique pleasure through beautifull and attractive visual } \\
\text { scenery } \\
\text { 2. Able to give philosophical knowledge regarding Kori's Architectural } \\
\text { Form adaptation as a traditional Balinese Design. } \\
\text { 3. Able to give knowledge regarding construction and material } \\
\text { arrangement (Asta Kosala-Kosali Concept Application) } \\
\text { 4. Giving explaination regarding Kori's function } \\
\text { 5. Able to give knowledge regarding ornament application in Kori's } \\
\text { body. }\end{array}$ \\
\hline \multirow[t]{7}{*}{2} & $\begin{array}{l}\text { Resident's } \\
\text { House } \\
\text { Layout } \\
\text { and } \\
\text { Condition }\end{array}$ & $\begin{array}{l}\text { Natah Layout } \\
\text { System }\end{array}$ & $\begin{array}{l}\text { 1. Giving a unique pleasure through visual scenery of Natah House } \\
\text { Layout Arrangement } \\
\text { 2. Able to give philosophical knowledge regarding Natah house layout } \\
\text { arrangement (Tri Hita Karana, Tri Mandala, Akasa-Pertiwi). } \\
\text { 3. Able to explained regarding vegetation that can be planted on Natah }\end{array}$ \\
\hline & & $\begin{array}{l}\text { Authentic Balinese } \\
\text { Traditional } \\
\text { Architecture Style }\end{array}$ & $\begin{array}{l}\text { 1. Giving a unique pleasure through visual scenery of Natah House } \\
\text { Layout Arrangement } \\
\text { 2. Able to give philosophical knowledge regarding Bale Building or Holy } \\
\text { Building Complex like Merajan } \\
\text { 3. Able to give knowledge regarding ornament application (Asta } \\
\text { Kosala-Kosali) }\end{array}$ \\
\hline & & $\begin{array}{l}\text { Balinese Traditional } \\
\text { Architecture ( } \\
\text { Modification) }\end{array}$ & $\begin{array}{l}\text { 1. Able to give philosophical knowledge regarding Bale Building or Holy } \\
\text { Building Complex like Merajan that has been renovated }\end{array}$ \\
\hline & & $\begin{array}{l}\text { The Existence of } \\
\text { Traditional Building ( } \\
\text { Bale Meten, Bale } \\
\text { Sakenem, Merajan, } \\
\text { Paon, Silver } \\
\text { Workshop, etc.) }\end{array}$ & $\begin{array}{l}\text { 1. Giving a unique pleasure through visual scenery of traditional } \\
\text { existing (bale, Paonbuilding in Resident's house compound. } \\
\text { 2. Able to give philosophical knowledge regarding Bale or Holy Building } \\
\text { Complex like Merajan } \\
\text { 3. Able to share knowledge regarding construction and material (Asta } \\
\text { Kosala-Kosali) }\end{array}$ \\
\hline & & $\begin{array}{l}\text { Traditional Building } \\
\text { Form }\end{array}$ & $\begin{array}{l}\text { 1. Giving a unique pleasure through visual scenery of traditional } \\
\text { existing (bale, Paonbuilding in Resident's house compound. } \\
\text { 2. Able to share knowledge regarding construction and material (Asta } \\
\text { Kosala-Kosali) } \\
\text { 3. Able to give philosophy regarding proportion determination } \\
\text { penentuan proporsi (asta kosala-kosali), }\end{array}$ \\
\hline & & $\begin{array}{l}\text { Functionality Aspects } \\
\text { of Balinese } \\
\text { Traditional Building }\end{array}$ & $\begin{array}{l}\text { 1. Able to share knowledge regarding function of each traditional } \\
\text { building (tri hita karana,tri mandala, etc.). } \\
\text { 2. Silver Crafting Workshop building for learning how to make silver } \\
\text { jewelry }\end{array}$ \\
\hline & & $\begin{array}{l}\text { Room's in Resident's } \\
\text { House }\end{array}$ & $\begin{array}{l}\text { 1. Can be change into tourism accomodations (Homestay) for tourist } \\
\text { and also giving the tourist an experience to participate in local } \\
\text { resident's daily activities (culture-tradition based adventure) }\end{array}$ \\
\hline 3 & $\begin{array}{l}\text { Resident's } \\
\text { Activities }\end{array}$ & $\begin{array}{l}\text { Traditional Silver } \\
\text { Craftsmanship }\end{array}$ & $\begin{array}{l}\text { 1. Can be traditional silver crafting workshop for tourist who wants to } \\
\text { know more about traditional silver craftsmanship }\end{array}$ \\
\hline
\end{tabular}

\section{Conclusions}

From the results of the analysis above, it can be concluded that the arrangement of potential tourist attractions from the residential architecture components found is related to one of the tourism interests, namely special tourism interest (WMK). This Special Interest Tourism is 
characterized by tourism activities with the main object being Culture; History; Ecotourism; and Tourism Village. In accordance with 6 (six) aspects of special interest tourism motivation, namely Novelty Seeking; Quality Seeking; Rewarding; Enriching; Adventuring; and Learning. Novelty seeking or the desire to find something unique is at the point of residential spatial planning, Kori, the layout of the resident's "Natah" house, Telajakan Garden; etc. Quality Seeking or the search for quality experience is at the point of the existence of traditional silver craftsmen and their pristine dwellings. Rewarding or appreciation for an object lies in attractive visuals that are generated from the culture of the Banjar Karang Dalem I settlement community, so as to be able to create spots that have tourism potential. Enriching or increasing knowledge can be found at the point where stories can be compiled in relation to the formation of settlement layout patterns, Telajakan Gardens, resident "Natah" house layout patterns, presence of Merajan, Tri Hita Karana application, Asta Kosala-Kosali application, etc. Adventuring or adventurous experiences are at the point of making residents' homes a tourist accommodation in the form of "homestays", thereby enabling tourists who stay overnight to have an adventure by participating in the daily lives of local residents. Learning or following the learning process of an activity that is carried out, is at the point of a traditional silver workshop, where through the craftsmen's workshop, tourists who come can also learn to make silver using the traditional system. Based on what was explained, of course the Banjar Karang Dalem I settlement, Bongkasa Pertiwi Village is very likely in the future to be developed as a community-based tourist attraction, as a creative and unique tourism.

\section{References}

Abdinagoro, S. B., \& Hamsal, M. (2019). Pengembangan Pariwisata Kepulauan Anambas: Tinjauan Pemasaran Stratejik. In Ary Suta Center, The Ary Suta Center Series : Strategic Management (pp. 11-31). Jakarta: The Ary Suta Center.

Anom, I., Suryasih, I., Suryawan, I., Mahagangga, I., \& Mertha, I. (2015). Kajian Pengembangan Desa Wisata Di Kabupaten Badung. Denpasar: Program Studi (S1) Destinasi Pariwisata, Fakultas Pariwisata, Universitas Udayana.

Badung, P. (2010). Peraturan Daerah Bupati Badung Nomor 47 Tahun 2010. Mangupura.

Pariwisata, M. K. (2010). PERMENBUDPAR No: PM.26/UM.001/MKP/2010. Menteri Kebudayaan dan Pariwisata.

Pradnya Dewi, N. (2018). Eksistensi Telajakan di Koridor Permukiman Desa Wisata Pinge, Kabupaten Tabanan. UNDAGI Volume 6, Nomor 1, 13-22.

Prasyanti, A. (2019). Pengembangan Pariwisata Berbasis Arsitektur Nusantara. Jakarta: Kementrian Pariwisata Republik Indoneisa.

Primastiana, F. S. (2018). Kajian Desa Jatiluwih sebagai Desa Wisata Berdasarkan Tingkat Partisipasi Masyarakat. Retrieved from Repository Universitas Pasundan: http://repository.unpas.ac.id/37309/1/FIKRI\%20PRIMASTIANA\%20SATARI-123060027PERENCANAAN\%20WILAYAH\%20DAN\%20KOTA.pdf

RI, K. (2019). Materi Pengembangan Desa Wisata. Jakarta: Kementrian Pariwisata Republik Indonesia.

Ristianti, N. S. (2015). Pengembangan Konsep Wisata Apung Kampung Nelayan Pesisir Balikpapan. RUANG Vol.1 No.1, 31-40.

Sugianto, A. (2016). Kajian Potensi Desa Wisata Sebagai Peningkatan Ekonomi Masyarakat Desa Karang Patihan Kecamatan Balong Ponorogo. Jurnal Ekuilibrium Vol.11 No.1, 56-65.

Widhiarini, N. N., Oktaviani, P., \& Permanita, N. D. (2019). Arsitektur Tradisiona; Bali Pada bangunan Puri Sebagai Daya Tarik Wisata Minat Khusus Dalam Mendukung Pengembangan Pariwisata Berkelanjutan. PUSAKA: Journal of Tourism, Hospitality, Travel and Business Event Vol.1, No.2, 46-52. 